\title{
Calculation of the ultimate efficiency of $p-n$-junction solar cells taking into account the semiconductor absorption coefficient
}

\begin{abstract}
A model based on the famous model of Shockley-Queisser for calculation the ultimate efficiency of solar cells has been proposed, taking into account the dependence of the semiconductor absorption coefficient on the band-gap and on the energy of the incident photons. The dependence of the ultimate efficiency of solar cells on thickness of the absorption layer was found out for homogeneous solar cells.

Streszczenie. Opierając się na znanym modelu Shockley`a-Queisser’a do obliczeń maksymalnej sprawności ogniw słonecznych, zaproponowano model biorąc pod uwagę zależność współczynnika absorpcji półprzewodników od pasma wzbronionego oraz energii padających fotonów. Określono zależność maksymalnej sprawności ogniw słonecznych od grubości warstwy absorpcyjnej dla jednorodnych ogniw słonecznych. (Obliczanie maksymalnej sprawności złącza p-n ogniw słonecznych na podstawie współczynnika absorpcji półprzewodników).
\end{abstract}

Keywords: solar cell, ultimate efficiency of solar cells, the Shockley-Queisser limit, absorption coefficient.

Słowa kluczowe: ogniwo słoneczne, maksymalna sprawność ogniw słonecznych, limit Shockley`a-Queisser`a, współczynnik absorpcji.

\section{Introduction}

Solar radiation has the largest potential among renewable energy sources $[1,2]$. The most common method of solar energy conversion into electricity is based on the use of solar cells (SCs), as it has shown promise in producing devices with a stable performance and highefficiency $[2,3]$. The main goal of the solar industry is to improve the efficiency of solar energy conversion into electricity by SCs. Solution of this problem requires continuous investigation of SCs which includes the study of different materials for constructing SCs and the development of the procedures of calculation the limits of efficiency of SCs.

To estimate the ultimate efficiency of a solar cell the well-known model of Shockley and Queisser is commonly used. Shockley and Queisser suggested that the carrier generation in the solar cell is defined by a detailed balance between light absorption and radiative recombination [4]. According to this model, the carrier mobility is infinite and all incident photons with the energies above the band-gap are absorbed. Thus, this model does not consider the dependence of the absorption coefficient on the semiconductor band-gap and on the energy of the incident light [5]. However, the data of the ultimate efficiency of solar cells based on different semiconductors with different optical properties are very important $[6,7]$.

We have developed a procedure for calculating the ultimate efficiency of SCs, taking into account the dependence of the absorption coefficient on the semiconductor band-gap and on the energy of the incident light. The effect of the thickness of the absorption layer on the ultimate efficiency of direct-band semiconductor solar cells was demonstrated for two cases: for the case of a total concentration of solar radiation and accounting the solid angle at which the Sun can be seen.

\section{The Shockley-Queisser model for solar cells}

Shockley and Queisser developed a formalism to calculate the limit of efficiency of a $p$ - $n$-junction solar cell [4]. They suggested that the generation of carriers in the SC is defined by a detailed balance between light absorption and radiative recombination.

Ideally, the carrier mobility is infinite, and the position of the Fermi level is quasi invariant. Also ideally, the surface recombination velocity is zero. In equilibrium, the energies of two quasi-Fermi levels ( $E_{F V}$ for the p-type semiconductor and $E_{F C}$ for the n-type semiconductor) are the same. The electric contact between semiconductors of two types is supposed to be ideal. The voltage $V$ appearing between the two electrodes is defined by the difference in the quasiFermi levels of the majority carriers and can be obtained from the following equation:

$$
e V=E_{F C}-E_{F V},
$$

where $e$ is the elementary charge.

The total power density of the Sun radiation $H$ can be found from the Stefan-Boltzmann law:

$$
H=\sigma T_{s}^{4},
$$

where $\sigma$ is the Stefan-Boltzmann constant, $T_{s}=5800 \mathrm{~K}$ is the temperature of the Sun.

When light absorption occurs in the semiconductor, the electrons make a transition from the valence band to the conduction band (the generation of electron-hole pairs takes place). In accordance with the principle of a detailed balance, the reverse process also takes place so the electrons make back transition from the conduction band to the valence band and emit photons. This process is called a radiative recombination. Ideally, the absence of any nonradiative recombination mechanism is supposed.

The difference between the number of absorbed and emitted photons determines the limit of the photocurrent density $J_{p h}$ in SCs [8]:

$$
J_{p h}=e\left(\Phi_{s}-\Phi_{r}\right),
$$

where $\Phi_{s}$ and $\Phi_{r}$ are the photon fluxes incoming and outgoing the solar cell, respectively. The streams of photons are determined by Planck's equation [9]:

$$
\begin{aligned}
& \Phi_{s}=\xi \frac{2 \pi \cdot \sin ^{2} \vartheta_{S}}{h^{3} \cdot c^{2}} \int_{E g}^{\infty} \frac{\varepsilon^{2} \mathrm{~d} \varepsilon}{\exp \frac{\varepsilon}{k \cdot T_{s}}-1}, \\
& \Phi_{r}=\xi \frac{2 \pi}{h^{3} \cdot c^{2}} \int_{E g}^{\infty} \frac{\varepsilon^{2} \mathrm{~d} \varepsilon}{\exp \frac{\varepsilon-e \cdot V}{k \cdot T_{a}}-1},
\end{aligned}
$$

where $\xi$ is the absorptivity or the emissivity (according to Kirchhoff's law of thermal radiation we consider that the 
absorptivity is equal to the emissivity); $\vartheta_{S}$ is the solid angle at which the Sun can be seen; $T_{a}$ is the temperature of the $\mathrm{SC} ; h$ is Planck's constant; $c$ is the speed of light; $k$ is Boltzmann's constant; $E g$ is the band-gap width.

Shockley and Queisser supposed that all incident photons with the energies above the band-gap energy are absorbed, i.e. $\xi=1$ [4].

If the filling factor of SC I-V characteristics tends to unity, the efficiency of SC $\eta$ [2] is equal to

$$
\eta=\frac{e V\left(\Phi_{s}-\Phi_{r}\right)}{\sigma T_{s}^{4}} .
$$

\section{The modified Shockley-Queisser model}

Unlike Shockley and Queisser, we take into account that $\xi<1$. Absorptivity $\xi$ is defined by the following formula according to the Lambert-Beer law:

$$
\xi=\frac{I_{0}-I_{0} \exp (-\alpha d)}{I_{0}}=1-\exp (-\alpha d),
$$

where $I_{0}$ is the intensity of the incident light, $\alpha$ is the absorption coefficient, $d$ is the thickness of the absorption layer.

We suggest that the absorption coefficient of the allowed direct dipole transitions is determined by the following equation [10-12]:

$$
\alpha(h v)=\frac{\pi e^{2}\left(2 m_{r}\right)^{3 / 2} E_{g}}{n \varepsilon_{0} m_{e} h^{3} c v}\left(h v-E_{g}\right)^{1 / 2},
$$

where $n$ is the refraction index of the semiconductor; $m_{e}$ is the effective mass of the electron; $m_{r}$ is the reduced effective mass; $\varepsilon_{0}$ is the electric constant.

For the majority of direct band semiconductors the absorption coefficient can be calculated from the following expression [13]:

$$
\alpha(h v)=A \cdot E_{g} \frac{\left(h v-E_{g}\right)^{1 / 2}}{h v},
$$

where $\alpha$ is measured in $\mathrm{cm}^{-1}, h v$ and $E_{g}$ are measured in eV. The constant $A$ in expression (9) is determined by the properties of a particular material and its value varies in the range of about $\left[10^{4} ; 10^{5}\right] \mathrm{cm}^{-1}(\mathrm{eV})^{-1 / 2}$.

For example, we obtained the following values of constant $A$ (in $\mathrm{cm}^{-1}(\mathrm{eV})^{-1 / 2}$ ) for some materials using equation (8): $\operatorname{lnSb}\left(2 \cdot 10^{4}\right), \ln A s\left(3.2 \cdot 10^{4}\right)$, GaSb $\left(3.4 \cdot 10^{4}\right)$ GaAs $\left(4.7 \cdot 10^{4}\right)$, InP $\left(5.2 \cdot 10^{4}\right), \quad$ ZnSe $\left(7.9 \cdot 10^{4}\right), \quad$ ZnO $\left(1.1 \cdot 10^{5}\right)$, GaN $\left(1.1 \cdot 10^{5}\right)$.

Using equation (8) for the absorption coefficient, the ultimate efficiency of the solar cell can be calculated more precisely from expressions (6) and (4-5).

\section{Ultimate efficiency of $p$-n-junction solar cells}

We also considered the light absorption in solar cells in two cases: in the case of a total concentration of solar radiation and in the case of normal concentration taking into account the solid angle at which the Sun can be seen.

For the case of a total concentration of solar radiation $\vartheta_{s}=4 \pi s r$, or $\vartheta_{s}=6.65 \cdot 10^{-5} \mathrm{sr}$ (the solid angle at which the Sun can be seen) for the case of normal concentration [11].
Fig. 1 shows the results of calculation of SC efficiency for $\xi=1$ corresponding to the Shockley-Queisser model.

If $T_{a}=0 \mathrm{~K}$ (plot 1) then we obtain the well-known dependences of SC efficiency on the band-gap of the photoactive material which were obtained earlier by Shockley and Queisser. The curves for a total concentration and normal concentration coincide with each other for $T_{a}=0 \mathrm{~K}$ due to the absence of a term describing the radiation loss. It is also seen from Fig. 1 that at room temperature the efficiency decreases because of a non-zero term describing the radiation loss (see equations (5) and (6)).

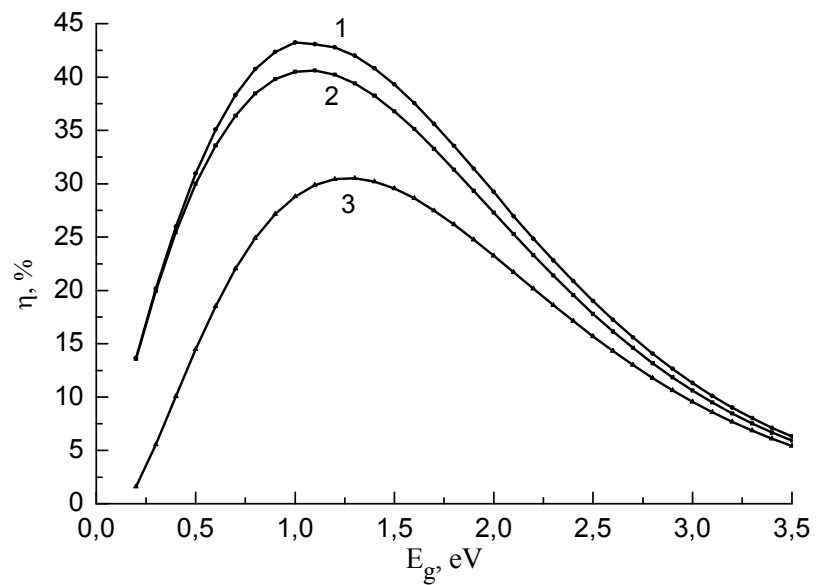

Fig.1. The dependences of the maximum efficiency of solar cells on the semiconductor band-gap at $\xi=1$ : $1-T_{a}=0$; $2-T_{a}=300 \mathrm{~K}, \vartheta_{s}=4 \pi \mathrm{sr} ; 3-T_{a}=300 \mathrm{~K}, \vartheta_{s}=6.65 \cdot 10^{-5} \mathrm{sr}$.

Fig. 1 shows that the maximum efficiency is about $43.5 \%$ at the band-gap of $1.0-1.1 \mathrm{eV}$ at $0 \mathrm{~K}$ and doesn't depend on the conditions of illumination of the SCs. At a temperature near $300 \mathrm{~K}$ in conditions of a total concentration of the solar radiation the maximum efficiency corresponds to $1.0-1.1 \mathrm{eV}$, but its value is smaller and approximately equals to $41 \%$. At the normal temperature there is a considerable influence of the degree of concentration of the radiation on the dependency of the maximum of efficiency on the semiconductor band-gap: for normal concentration of radiation the maximum of efficiency shifts to the range $1.2-1.3 \mathrm{eV}$ and its value equals approximately $31 \%$.

If the absorptivity $\xi<1$ and is determined by (7) and (9), the efficiency of SCs depends on the thickness of the absorption layer and on the value of the constant $A$ in equation (9) for the absorption coefficient.

Fig. 2 and Fig. 3 show the results of calculation the efficiency of SCs for several values of thickness of the absorption layer in cases of total concentration and normal concenctration, respectively. The constant $A$ in equation (9) was assumed to be equal to $10^{5} \mathrm{~cm}^{-1}(\mathrm{eV})^{-1 / 2}$. Obviously, if the value of this constant for some material is definite times less than $10^{5} \mathrm{~cm}^{-1}(\mathrm{eV})^{-1 / 2}$ then the obtained dependencies will correspond to the cases of the same times higher thickness of the absorption layer, as it follows from equation (7).

The analyses of Fig. 2 and Fig. 3 reveals that maximum of efficiency of SC becomes higher when the thickness of the absorption layer is increased. When constant $A$ in the absorption coefficient (see eq. (9)) is equal to $10^{5} \mathrm{~cm}^{-1}(\mathrm{eV})^{-1 / 2}$ and the thickness of the absorption layer is increased above $1 \mu \mathrm{m}$ then the obtained dependencies 
tend to the dependencies corresponded to the ShockleyQueisser model (Fig. 1).

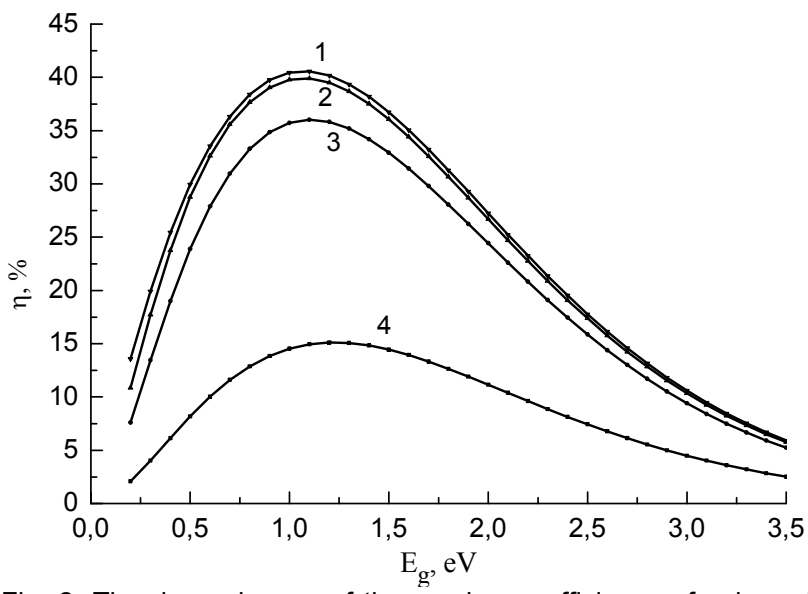

Fig. 2. The dependences of the maximum efficiency of solar cells on the semiconductor band-gap in the case of total concentration of radiation and various thicknesses of the absorption layer: $1-d=100 \mu \mathrm{m} ; 2-d=1 \mu \mathrm{m} ; 3-d=0.5 \mu \mathrm{m} ; 4-d=0.1 \mu \mathrm{m}$.

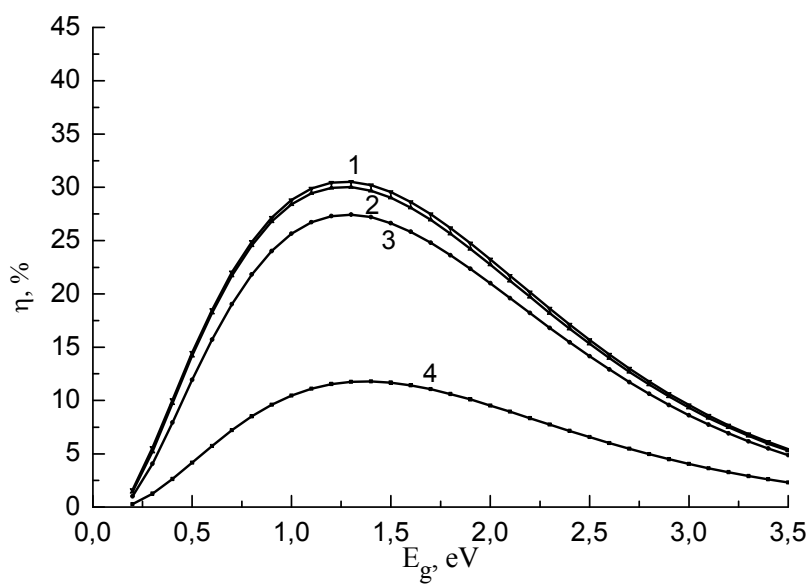

Fig. 3. The dependences of the maximum efficiency of solar cells on the semiconductor band-gap in the case of normal concentration of radiation and various thicknesses of the absorption layer: $1-d=100 \mu \mathrm{m} ; 2-d=1 \mu \mathrm{m} ; 3-d=0.5 \mu \mathrm{m} ; 4-d=0.1 \mu \mathrm{m}$.

So, the increase in thickness of the element more than $1 \mu \mathrm{m}$ is not expedient. This result is in a good agreement with [14] for $\mathrm{Cu}(\mathrm{In}, \mathrm{Ga})(\mathrm{S}, \mathrm{Se})_{2}-\mathrm{SC}$. Actually, both in cases of total and normal concentration of radiation the thickness of the absorption layer substantially effects on the dependency of the efficiency of SCs on the band-gap if the thickness is less than $1 \mu \mathrm{m}$. When the thickness is decreased the maximum of efficiency shifts to the range of greater $E_{g}$. The increase of thickness more than $1 \mu \mathrm{m}$ doesn't cause any substantial changes. Note that these conclusions are actual for the substances with the constant $A$ in equation (9) equals $10^{5} \mathrm{~cm}^{-1}(\mathrm{eV})^{-1 / 2}$, for example GaN. For InSb with a constant $A=2 \cdot 10^{4} \mathrm{~nm}^{-1}(\mathrm{eV})^{-1 / 2}$ the expedient thickness of the absorption layer is equal approximately to $5 \mu \mathrm{m}$.

\section{Conclusion}

Thus, we have developed a model for calculation the maximum efficiency of solar cells based on the well-known Shockley-Queisser model taking into account the dependence of the absorption coefficient on the semiconductor band-gap and on the energy of the incident light. The dependence of the ultimate efficiency of solar cells on thickness of the absorption layer was found out for homogeneous solar cells in the considered cases: in the case of a total concentration of solar radiation and in the case of normal concentration taking into account the solid angle at which the Sun can be seen.

Authors: PhD Mikhail Tivanov, Belarusian State University, Physics Faculty, 4, Nezavisimosti av., 220030 Minsk, Belarus, e-mail: tivanov@bsu.by; Junior Researcher Alexander Moskalev, Belarusian State University, Physics Faculty, 4, Nezavisimosti av., 220030 Minsk, Belarus, e-mail: maskaliou@bsu.by; PhD Iryna Kaputskaya, Belarusian State University, Physics Faculty, 4, Nezavisimosti av., 220030 Minsk, Belarus, e-mail: kaputskaya@bsu.by, Prof. Paweł Żukowski Lublin University of Technology, 38a, Nadbystrzycka Str., 20-618 Lublin, Poland

\section{REFERENCES}

[1] Sen Z., Solar energy in progress and future research trends, Progress in Energy \& Combustion Science, 30 (2004), 367-416

[2] Gremenok V.F., Tivanov M.S., Zalesski V.B., Solar cells based on semiconductor materials, International Scientific Journal for Alternative Energy and Ecology, 69 (2009), n. 1, 59-124

[3] Rai G.D., Solar Energy Utilization, Khanna Publishers, 1980

[4] Shockley W., Queisser H.J., Detailed Balance Limit of Efficiency of $p$-n Junction Solar Cells, Journal of Applied Physics, 32 (1961), 510-519

[5] Liao B., Hsu W., An Investigation of Shockley-Queisser Limit of Single p-n Junction Solar Cells. Rep., 2.997, MIT, Cambridge, MA., (2011)

[6] Wolfe M., Efficiency in Solar Cells. Department of Physics and Astronomy, Drexel Univerisity (2013)

[7] Razykov T.M., Ferekides C.S., Morel D., Stefanakos E., Ullal H.S., Upadhyaya H.M., Solar photovoltaic electricity: Current status and future prospects, Solar Energy, 85 (2011), 1580-1608

[8] Baruch P., De Vos A., Landsberg P.T., Parrott J.E., On some thermodynamic aspects of photovoltaic solar energy conversion, Solar Energy Materials and Solar Cells, 36 (1995), 201-222

[9] Planck M., Distribution of energy in the spectrum, Annalen der Physik, 4 (1901), 553-563

[10] Dresselhaus M.S., Solid state physics. Part II, Optical Properties of Solids, MIT, (2001)

[11] Abrams Z.R., Gharghi M., Niv A., Gladden C., Zhang X., Theoretical efficiency of 3rd generation solar cells: Comparison between carrier multiplication and down-conversion, Solar Energy Materials and Solar Cells, 99 (2012), 308-315

[12] Faist J., Optical Properties of Semiconductors, ETH Zurich, (2008)

[13] Garg H.P., Prakash J., Solar Energy: Fundamentals and Applications, Tata McGraw-Hill, (1997)

[14] Tivanov M., Astashenok L., Fedotov A., Węgierek P., Effect of absorbing layer thickness on efficiency solar cells based on $\mathrm{Cu}(\mathrm{In}, \mathrm{Ga})(\mathrm{S}, \mathrm{Se})_{2}$, Przeglad Elektrotechniczny 88 (2012), n. 7a, 321-323 